\title{
Hydrogen-Based Energy Storage Systems for Large-Scale Data Center Applications
}

\author{
Asha-Dee N. Celestine (D), Martin Sulic, Marika Wieliczko and Ned T. Stetson *
}

US Department of Energy, Hydrogen and Fuel Cell Technologies Office, 1000 Independence Avenue SW, Washington, DC 20585, USA; asha-dee.celestine@hq.doe.gov (A.-D.N.C.); martin.sulic@ee.doe.gov (M.S.); marika.wieliczko@ee.doe.gov (M.W.)

* Correspondence: ned.stetson@ee.doe.gov

Citation: Celestine, A.-D.N.; Sulic, M.; Wieliczko, M.; Stetson, N.T. Hydrogen-Based Energy Storage Systems for Large-Scale Data Center Applications. Sustainability 2021, 13, 12654. https://doi.org/10.3390/ su132212654

Academic Editors: Claudio Corgnale, Chiara Milanese and Adam Smoliński

Received: 3 September 2021

Accepted: 8 November 2021

Published: 16 November 2021

Publisher's Note: MDPI stays neutral with regard to jurisdictional claims in published maps and institutional affiliations.

Copyright: (C) 2021 by the authors. Licensee MDPI, Basel, Switzerland. This article is an open access article distributed under the terms and conditions of the Creative Commons Attribution (CC BY) license (https:/ / creativecommons.org/licenses/by/ $4.0 /)$.

\begin{abstract}
Global demand for data and data access has spurred the rapid growth of the data center industry. To meet demands, data centers must provide uninterrupted service even during the loss of primary power. Service providers seeking ways to eliminate their carbon footprint are increasingly looking to clean and sustainable energy solutions, such as hydrogen technologies, as alternatives to traditional backup generators. In this viewpoint, a survey of the current state of data centers and hydrogen-based technologies is provided along with a discussion of the hydrogen storage and infrastructure requirements needed for large-scale backup power applications at data centers.
\end{abstract}

Keywords: hydrogen; backup power; large-scale; material-based; energy storage; data centers

\section{Introduction}

Hydrogen continues to garner increasing interest to help address climate challenges, especially in hard to decarbonize applications such as heavy duty transportation and industrial applications, and to enable a clean electric grid through long duration energy storage $[1,2]$. Hydrogen has significant potential for use in a wide range of established areas and several developing applications [3]. While there has been significant effort in hydrogen and fuel cell technology research and development (R\&D) for transportation [4-9], renewed interest in stationary applications is emerging. In particular, large-scale stationary applications which do not have the same strict constraints as fuel cell electric vehicles, such as storage density, storage system mass, and thermal heat management, are prime candidates for incorporating hydrogen technologies [10]. However, to replace any incumbent technology, the cost and performance of the incoming technology is critical. For hydrogen to be widely adopted, the production cost is key. To enable advancements in the field, Hydrogen Shot, the first of the U.S. Department of Energy's (DOE) Energy Earthshot Initiatives aimed at accelerating breakthroughs in clean energy solutions, was announced in 2021. This Energy Earthshot will focus on reducing the cost of clean hydrogen production by $80 \%$ to USD 1 for 1 kilogram in 1 decade, thereby enabling hydrogen deployment at scale [11].

Hydrogen can be deployed to fill the need for backup power due to its capacity for large-scale, long-term, and grid-decoupled energy storage. Hydrogen-based technologies can provide consistent, reliable, off-grid power that is both rapidly available and on demand in the event of a power failure. Critical facilities that provide emergency services, such as hospitals, police stations and fire stations, water and wastewater facilities, and communication systems used to support essential public services, typically rely on backup diesel generators to ensure continuous power if the electrical grid is down. Water facilities, for example, need to be able to maintain water pressure to fight devastating fires. Additionally, nonattainment zones, such as industrial areas, ports, and airports, do not meet primary air pollutant standards and represent another area where hydrogen can address emission reductions. The U.S. Environmental Protection Agency (EPA) maintains the EPA Green 
Book that contains detailed information including the status of nonattainment counties for all criteria pollutants throughout the United States [12,13]. There are currently over 2000 counties that are classified as moderate and above in accordance with the National Ambient Air Quality Standards (NAAQS) [14]. Furthermore, transitioning away from diesel to hydrogen will directly benefit Environmental Justice communities in addition to facilitating the goal of the Justice40 Initiative. The Initiative, set forth by the Biden administration in 2021, has the goal of delivering at least $40 \%$ of the overall benefits from federal investments in climate and clean energy to disadvantaged communities [15-17].

Aside from critical facilities, large data centers cannot afford to lose power even for a moment, and similarly rely on generators to provide up to $72 \mathrm{~h}$ of backup power [18]. The use of diesel generators for backup power, especially on a large scale, is a matter of concern regarding harmful emissions and increasing regulations limiting their acceptable use [19]. The EPA established the Diesel Emissions Reduction Act (DERA) in 2005 [20], which aims to facilitate a progressive reduction in emissions from vehicular and generator diesel engines by giving the EPA new grant and loan authority. The DERA targeted generator emissions of no more than $3.5 \mathrm{~g} / \mathrm{kWh} \mathrm{CO}, 0.67 \mathrm{~g} / \mathrm{kWh} \mathrm{NOx}$, and $0.03 \mathrm{~g} / \mathrm{kWh}$ particulate matter, among others, by 2015. In 2020, DERA was reauthorized, and the program will continue to award grants and rebates to achieve diesel emissions reduction [20,21]. While recently proposed legislation seeks to provide certain exemptions to critical facilities, data centers do not qualify for these exemptions [22]. Generators, whether diesel or biofuel, also contribute substantially to noise pollution, producing noise ranging anywhere from city traffic levels (85 decibels) for a small $50 \mathrm{~kW}$ unit to the sound of a jet airplane in flight (105 decibels) for large $1500 \mathrm{~kW}$ systems [23]. Within certain municipalities, diesel generators would require the use of noise reducing technology to mitigate the health hazards to local populations.

Nonetheless, the data center industry has shown enormous growth in recent years as technological advances increase data creation and the subsequent need for its storage. In 2018, 2.5 exabytes $\left(1 \times 10^{18}\right)$ of data were generated by humans each day, and it is estimated that it will increase to 463 exabytes by 2025 [24,25]. By that same year, the total global volume of data that will be created, captured, copied, and consumed is anticipated to reach $>150$ zettabytes $\left(1 \times 10^{21}\right)$ [26-28], which may very well be an underestimation as business relations, education, shopping, etc., have turned digital in response to the COVID-19 pandemic [29]. As the data economy grows, fueled by a feedstock with seemingly infinite supply and demand, so too will data centers in both number and size. There are multiple options available for carbon neutral or carbon zero data center backup power systems, including the use of lithium-ion batteries, biofuel generators, and hydrogen fuel cells. The choice of system would depend primarily on the amount and duration of backup power required and the results of techno-economic and environmental analyses would need to be considered. Hydrogen-based backup power systems hold significant potential for providing the uninterrupted power needed by individual data centers and data center hubs, and these systems are the focus of this viewpoint [30]. Using renewably sourced hydrogen and scaling up to primary power could realize significant carbon footprint reduction for data centers of various sizes. These factors highlight a prime opportunity for hydrogen fuel cell systems to enter the market and not only replace but surpass the performance of currently used systems.

\section{Discussion}

\subsection{Power Requirements for Data Centers}

Modern data centers can generally be grouped into five categories: hyperscale, colocation, wholesale colocation, enterprise, and telecom. While classification systems are growing in acceptance, grouping by power requirements is challenging because, currently, there are not clearly defined national or international standards. Some international standards for data center facilities and infrastructure have been published, e.g., EN50600 [31] and ISO22237 [32-35], while the Telecommunications Industry Association [36] and the Uptime Institute [37] have established separate classifications in the US, further refining 
the 5 general categories into 11 different types that define data centers by building space requirements and site infrastructure [38]. Within this wide range, data centers can be sorted by facility size, from $<10 \mathrm{~m}^{2}$ to $>40,000 \mathrm{~m}^{2}$, which have power requirements from a few kilowatts $(\mathrm{kW})$ for a small server or telecommunication station to hundreds of megawatts (MW) for running hundreds of thousands of cloud-based computing servers. The majority of data centers in the US are small, with most in the range of 1-3 MW total power; however, these data centers are typically embedded in organizations with data center needs, in contrast to co-location and hyperscale data centers that are typically 10-100 MW in range.

Power is typically the largest expenditure in operating a data center, with the amount varying according to data center type, energy source, region, and efficiency [39]. A key metric of data center power efficiency is measured by Power Usage Effectiveness (PUE), the ratio of the total annual energy to the annual energy used by the Information Technology (IT) equipment. Figure 1 illustrates the average data center facility power distribution in 2014 compared to that forecasted for 2020, highlighting the progressive increase in facility efficiency and scale [38]. Previous estimates for increases in energy consumption by data centers have been mitigated by improvements in PUE [40]. Models have estimated that PUE values will improve by 1\% per year through 2020 [38]. Smaller data centers in the US have an average PUE value of 2.0 or greater, while hyperscale data centers can have PUE values of 1.2 or less. Smaller data centers are usually integrated into multi-use buildings, rather than purpose-built structures, which might limit some of the energy efficiency technologies. Additional inefficiencies arise from the difficulty in modernizing smaller systems as industry demand moves toward large-scale facilities.
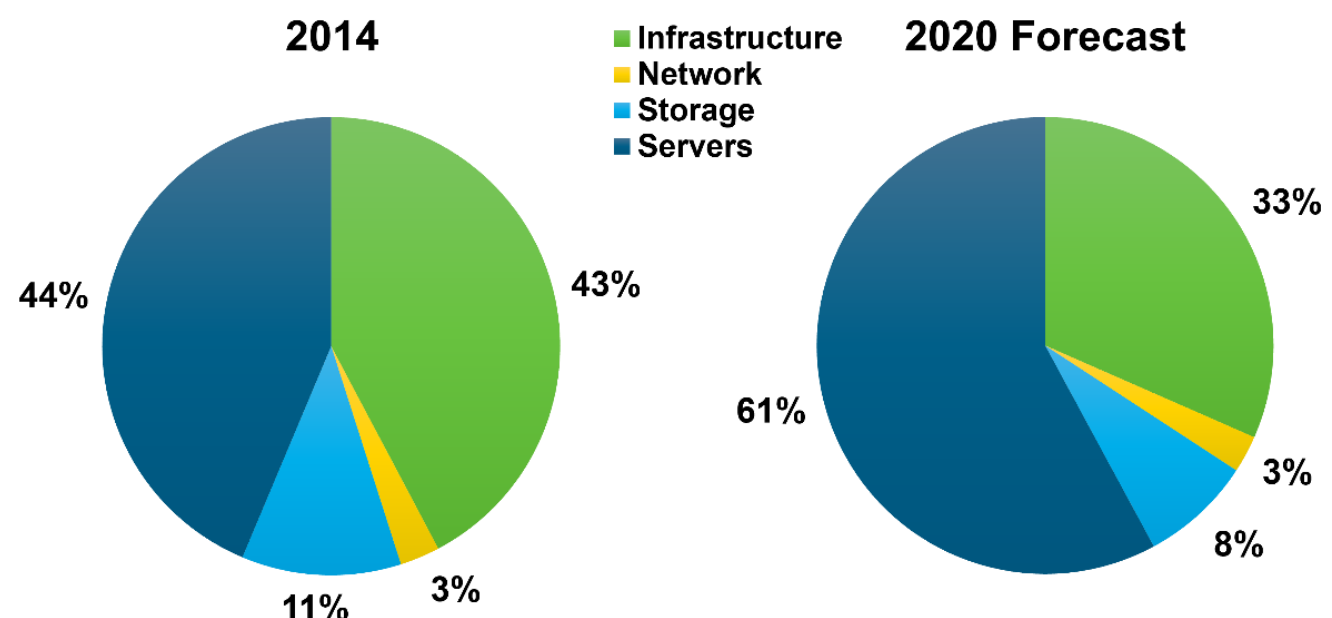

Figure 1. Forecasted data center power distribution shifts from 2014 to 2020 (reported in 2016) that coincides with the rise in hyperscale data centers and cloud-based facilities [38].

As cloud services claim a growing share of the global market, the impact of large, hyperscale data centers is expected to continue. Currently, there are approximately 540 hyperscale centers globally, up from 500 in 2019, with 26 new centers in the first half of 2020. As the number of hyperscale facilities increases, so does their size. For example, the Range International Information Group has built the world's largest data facility in China $\left(585,000 \mathrm{~m}^{2}\right)$, and when the Citadel in Northern Nevada is complete, it will occupy $670,000 \mathrm{~m}^{2}$ and require up to $650 \mathrm{MW}$ to operate. During this unprecedented growth, the industry looks towards the future of data centers at the gigawatt $(\mathrm{GW})$ scale. Amazon data centers in Ashburn, Virginia, use approximately 1000 MW currently but are spread over multiple facilities, whereas the US-Norwegian company Kolos is in the process of building a massive facility in a small Norwegian village near the Arctic circle with plans to expand to $1 \mathrm{GW}$. The potential reliance on diesel generators for backup power on this scale comes with heavy implications for their carbon footprint. 
It is here that hydrogen-based energy storage systems are an attractive alternative that not only provides the required backup power security but also the opportunity for renewable energy incorporation. Table 1 illustrates the hydrogen quantities that would be needed over a $24 \mathrm{~h}$ and $72 \mathrm{~h}$ period by hydrogen-based data center backup systems of varying power requirements. The hydrogen needs for the Citadel and Kolos data center projects are also included for comparison. At these scales, advances in hydrogen storage and delivery technology are needed, but regardless of the size of the data center and its critical loads, backup generation is modular. A demo could be scalable to any power level, where a reasonable estimate would be 5-20 MWs for backup power. Furthermore, backup systems require redundancy, which is vital to ensure that an uninterruptible power supply (UPS) system is always available, further strengthening the opportunity proposition for hydrogen fuel cell implementation as companies move towards zero carbon emission goals [41-43].

Table 1. Hydrogen required to sustain backup power demands for data centers over a $24 \mathrm{~h}$ and $72 \mathrm{~h}$ period. Assumption: $50 \%$ fuel cell efficiency.

\begin{tabular}{cccc}
\hline $\begin{array}{c}\text { Data Center Scale } \\
\left(\mathbf{m}^{\mathbf{2}} \mathbf{)}\right.\end{array}$ & $\begin{array}{c}\text { Power Requirements } \\
\text { (MW) }\end{array}$ & $\begin{array}{c}\text { 24 h Backup } \mathbf{H}_{\mathbf{2}} \\
\text { (Tonnes) }\end{array}$ & $\begin{array}{c}\mathbf{7 2} \text { h Backup } \mathbf{H}_{\mathbf{2}} \\
\text { (Tonnes) }\end{array}$ \\
\hline$<10$ & 0.1 & 0.14 & 0.43 \\
1000 & 10 & 14.4 & 43.2 \\
$>40,000$ & 150 & 216 & 648 \\
Citadel & $650^{1}$ & 936 & 2808 \\
Kolos & $1000^{1}$ & 1440 & 4320 \\
\hline
\end{tabular}

${ }^{1}$ Upon completion of the facility.

\subsection{Hydrogen Fuel Cells for Data Centers}

In addition to environmental concerns, the need for consistent and reliable power is also a matter of cost effectiveness. An unplanned data center outage costs USD 740K on average, or USD 8851 per minute [18]. Failures in traditional UPS and backup generators have been known to cause extensive and costly physical damage [44]. In addition to repairs, providers may be required by service contracts to give rent abatements to customers in the event that electrical power is dropped in the section(s) of the data center where their servers are located, bolstering the financial incentive to maintain reliable power [45]. Power malfunctions can also pose a national security risk. For example, the US National Security Agency (NSA) data center in Bluffdale, Utah experienced 10 meltdowns in only 13 months, causing hundreds of thousands of dollars in damage and delaying the slated 2013 opening of the NSA's 65 MW facility $[43,46]$.

For backup power demand, fuel cells deliver a fast and dynamic response [47], consistent and reliable power, and offer several operational advantages. Not only do fuel cell backup power systems produce no harmful local emissions, but they also operate at silent to near-silent levels, such that they can be placed within a facility to best meet the needs of the data center rather than be restricted to the exterior of a building. In contrast to diesel generators, which require routine maintenance and start-up checks during periods of non-use, fuel cells system are much simpler mechanically, and require less stringent maintenance protocols [48]. Currently, Polymer Electrolyte Membrane (PEM) fuel cell electrical efficiency stands at approximately 50\% (compared to 30-35\% for diesel), and the technology is continuously being improved upon, adding to the financial incentive to adopt this technology with little risk considering redundancy needs. Additionally, these modular systems can be custom matched to a data center's changing needs readily, as stacks can be added to accommodate increasing backup power requirements.

To facilitate the exploration of such ideations, the US Department of Energy's Hydrogen and Fuel Cell Technologies Office (HFTO) and the National Renewable Energy Laboratory (NREL) held a workshop in 2019, bringing together stakeholders from the technology and computer industry, the hydrogen production and delivery industry, the 
fuel cell industry, national laboratories, and universities to discuss the role that hydrogen fuel cell systems can play in providing prime and backup power to data centers [48]. Several suggestions for configurations were presented and discussed. One conceptual design is to place fuel cells inside the facility within proximity of the servers and distribute hydrogen into the building rather than electricity. This arrangement could reduce cost and simplify backup systems by replacing the large diameter copper wiring $(\sim 25 \mathrm{~mm})$ required to transmit power from exterior located fuel cells to servers with far less expensive stainless-steel hydrogen piping. In addition, the configurable potential of hydrogen backup systems, compared to diesel, would allow for greater ease in the retrofit of existing facilities and their incorporation into small and urban areas as well as green- and brownfield sites. Importantly, the keys to industry acceptance were identified, which included standardized design and equipment and the endorsement by recognized industry leaders. The workshop concluded that for companies to accept any new technology related to data centers, the technology must be put into practice, demonstrated at scale, and accepted by engineers of record and code officials.

In early 2020, Microsoft declared its commitment to becoming carbon-negative by 2030 [49], and in July of that year, the company announced that it had tested hydrogen fuel cells for backup power on a row of data center servers for 48 consecutive hours. The demonstration, using a 250 kW PEM system, was completed outside of Salt Lake City, Utah with the system developer Power Innovations and inspired by a proof-of-concept system installed at the National Renewable Energy Laboratory (NREL) [50]. Prior to this demonstration, Microsoft had already co-located a $300 \mathrm{~kW}$ fuel cell and a data center at a wastewater treatment plant in Cheyenne, Wyoming that operates off of the renewable methane generated by the facility. Microsoft, however, is not unique in these efforts to incorporate such advanced renewable energy technologies into established systems. Apple has installed $10 \mathrm{MW}$ of fuel cells coupled with solar panels in its Maiden, North Carolina iCloud data center, while eBay operates $6 \mathrm{MW}$ of fuel cells in its South Jordan, Utah data center. Additionally, CenturyLink powers its Irvine, California data center with a 500-kW fuel cell system, while other adopters include AT\&T, Google, Verizon, JPMorgan Chase, Williams-Sonoma, Cox, the First National Bank of Omaha, Equinix, and more [51]. While most of these current fuel cell installations operate on natural gas, the potential for hydrogen-powered systems to approach wide-spread integration is underscored by industry leaders accelerating the effort.

\subsection{Hydrogen-Based Energy Storage for Data Centers}

Based on the scales of hydrogen required to fulfil the demands of modern-day and foreseen large-scale data centers, the practical needs of hydrogen storage must be considered. For transportation applications, the density, volume, and system mass are important factors which do not necessarily transcribe to the same limitations when considering largescale, stationary applications. The following discussion explores the currently available and emerging technologies for hydrogen storage on such scales, with an examination of the merits, performance gaps, and opportunities in each of the focus areas of the HFTO Hydrogen Storage Program's diverse portfolio. Hydrogen storage falls under two categories: physical storage and materials-based storage. While physical storage is the more mature technology [52], material-based systems hold great promise for high storage density and offer a wide range of versatility, including reversibility [52-55]. Figure 2 shows a scaled mockup of a hypothetical $9300 \mathrm{~m}^{2}$ data center operating at $200 \mathrm{MW}$, similar to a typical hyper-scale data center, and the volume of hydrogen-based energy medium required to sustain such a system for $72 \mathrm{~h}$ based on $50 \%$ fuel cell efficiency [56]. Note: Spherical storage vessels are shown in Figure 2 solely to illustrate the scale of storage volume-to-facility size based on hydrogen density per specified medium. They do not account for additional vessel requirements (e.g., insulation) or practical storage tank configuration. Metal hydrides $(\mathrm{MH})$ and liquid organic hydrogen carriers (LOHCs) provide the highest hydrogen density, up to $100 \mathrm{~kg} / \mathrm{m}^{3}$, requiring approximately 8.64 million liters for $72 \mathrm{~h}$ of backup power, in 
contrast to $\sim 4.45$ million liters of diesel. However, over $72 \mathrm{~h}$, approximately 12 million kilograms of $\mathrm{CO}_{2}$ emissions would be produced by that volume of diesel.

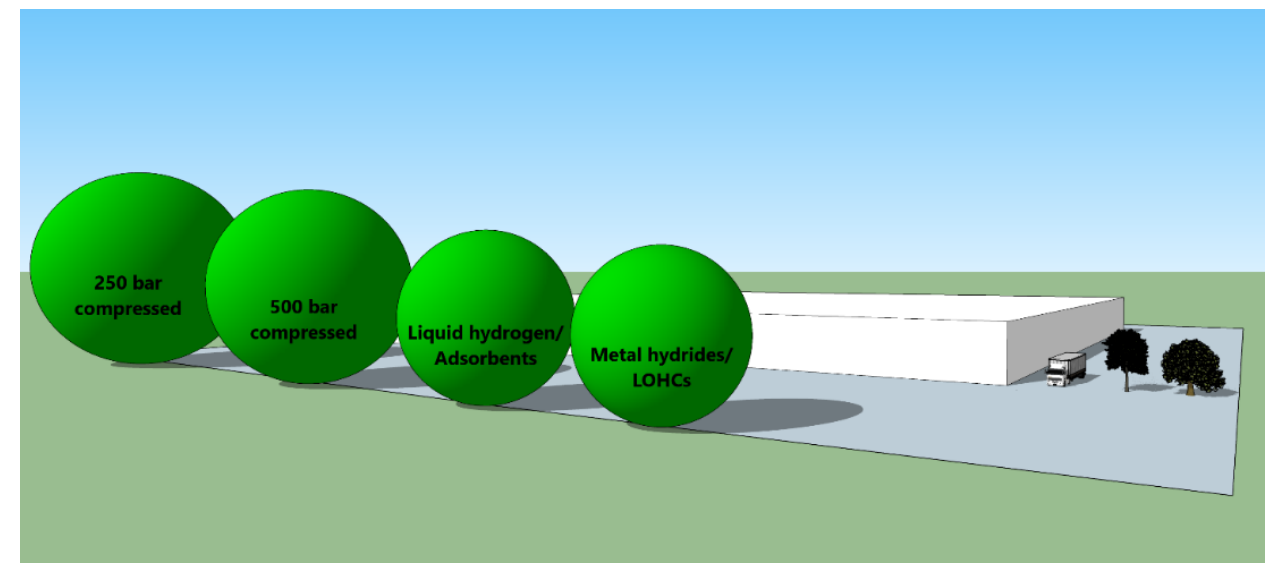

Figure 2. Hydrogen storage volumes required for up to $72 \mathrm{~h}$ of backup power for a $200 \mathrm{MW}, 9300 \mathrm{~m}^{2}$ data center facility: Volumes calculated based on storage medium densities for a (1) typical 250 bar compressed hydrogen transport $\left(18 \mathrm{~kg} / \mathrm{m}^{3}\right)$; (2) newer 500 bar composite transport tanks $\left(31 \mathrm{~kg} / \mathrm{m}^{3}\right)$; (3) liquid hydrogen, $\mathrm{LH}_{2}$, and adsorbents $\left(70 \mathrm{~kg} / \mathrm{m}^{3}\right)$; and (4) metal hydrides, $\mathrm{MH}$, and liquid organic hydrogen carriers, LOHCs, $\left(100 \mathrm{~kg} / \mathrm{m}^{3}\right)$. Radii of spheres: $250 \mathrm{bar}=22 \mathrm{~m}, 500 \mathrm{bar}=19 \mathrm{~m}$, $\mathrm{LH}_{2}$ /adsorbents $=14 \mathrm{~m}$, and $\mathrm{MH} / \mathrm{LOHCs}=12 \mathrm{~m}$. Facility is $\sim 12 \mathrm{~m}$ in height. Spherical storage vessels used for illustrative purposes only and do not indicate actual vessel design and configuration.

These power needs are amenable to a range of both established and emerging hydrogenbased energy storage technologies that have the potential to fulfill backup power requirements for the growing spectrum of data centers, and hydrogen storage is a key aspect of a fuel cell backup system. The main objective of any hydrogen storage system is to compactly contain hydrogen in the storage vessel or medium [57]. Additionally, an ideal storage system would be one where the intake and release of hydrogen is reversible [57]. Depending on the specific needs and available infrastructure, some hydrogen storage options may be more advantageous or available for rapid adoption.

\subsubsection{Physical Storage Options for Large-Scale Applications}

Large-scale physical storage options for hydrogen include storing it as a compressed gas or as a liquid $[10,58,59]$. Compressed gas storage is the most straightforward method but entails compressing hydrogen at high pressures due to hydrogen's low density at ambient temperature and pressure $\left(0.09 \mathrm{~kg} / \mathrm{m}^{3}\right)$ [10,58]. Typical tube trailer transports contain hydrogen at 250 bar $\left(18 \mathrm{~kg} / \mathrm{m}^{3}\right)$, whereas newer composite tank trailers are upwards of 500 bar $\left(31 \mathrm{~kg} / \mathrm{m}^{3}\right)$. It can be assumed that a site with stationary compressed hydrogen storage would be within this range. This technique, however, is an expensive option for large-scale, above ground hydrogen storage at data centers as it requires large storage volumes (Figure 2) and expensive high pressure tanks, which translate to high investment and operating costs [10]. For example, a $20 \mathrm{MW}$ data center would require approximately 30 tonnes of hydrogen per day for backup power, which translates to approximately $4800 \mathrm{~m}^{3}$ (4.8 million liters) of hydrogen at 250 bar for the recommended $72 \mathrm{~h}$ of available backup power.

Underground storage in salt caverns, depleted oil and natural gas reservoirs, or aquifers is a viable option for storing large amounts of compressed hydrogen with potential storage capacities of $100 \mathrm{GWh}$ [60-62]. In addition to higher storage volumes $\left(10-100 \times 10^{4} \mathrm{~m}^{3}\right)$ and pressures (up to 200 bar and higher), underground storage requires less above-surface space, has longer operating lifetimes, and provides greater security $[60,62,63]$. Hydrogen storage in salt caverns, while more geographically limited, represents the best option as the working gas volume (i.e., the stored gas that can be injected or withdrawn) is much 
higher than in depleted reservoirs and aquifers, and salt cavern storage facilitates multiple withdrawal and injection cycles per year [60]. Underground pipeline storage is also an amenable option particularly if an existing pipeline infrastructure can be used [10,64].

Storing hydrogen in the liquefied state is a more compact alternative, as the storage density of liquid hydrogen at atmospheric pressure is high $\left(\sim 71 \mathrm{~kg} / \mathrm{m}^{3}, 2.3 \mathrm{kWh} / \mathrm{L}\right)[10,52,58]$. However, cryogenic temperatures $(\sim 20 \mathrm{~K})$ are required for efficient liquid hydrogen storage which makes the liquefaction process both energy intensive and costly $[52,58,59]$ approximately one-third of the energy content of the hydrogen is needed for current liquefaction processes. Hydrogen boil-off loss, which is mainly due to heat transfer from the environment, is the primary concern in backup power scenarios [10]. This necessitates the use of bulky and expensive insulation, and/or expensive cryogenic refrigeration systems to minimize the amount of liquid hydrogen that evaporates, which can be as much as $5 \%$ per day $[10,58,59,65,66]$, and requires periodic replenishment regardless of whether or not there is a demand for backup power. Though liquid hydrogen may not be ideal in periodic backup scenarios, it could be feasible for regular usage or prime power. While less volume is needed to store enough liquid hydrogen for backup power compared to compressed hydrogen, the combination of high energy and capital costs, preferred proximity to liquefaction facilities, and issues with delivering and dispensing the hydrogen diminishes the suitability of using large-scale liquid hydrogen storage for data center applications $[10,58,59]$.

\subsubsection{Materials for Large-Scale Hydrogen-Based Energy Systems}

For stationary applications where hydrogen is used for backup power, extended periods of storage time may be required. As the requirements for stationary storage applications can vary, there is space for multiple technologies to advance large-scale hydrogen storage, which may not be practical for mobile applications, since mass and system volume are not as primary a concern. Hydrogen carriers encompass a broad scope of material-based options, from metal hydrides to adsorbents to chemical hydrogen carriers, that either physically (physisorption) or chemically (chemisorption) store hydrogen. These options may be one-way carriers, where the spent material is not reused after hydrogen is released, or two-way carriers, where the material can be regenerated on- or off-site for subsequent reuse. Research in the field is ongoing and continually advancing. For instance, the DOE's Hydrogen Materials Advanced Research Consortium's (HyMARC) main directive is to identify, study, and develop hydrogen carrier materials with optimal properties for various storage applications [67].

Metal hydrides, which include elemental, intermetallic, and complex hydrides, can provide compact storage of large amounts of energy with relatively low-pressure operation $[55,57,68]$. Hydrogen storage density is high in elemental metal hydrides where the hydrogen is chemically bonded to the metal [10,54,69]. Examples of these are $\mathrm{MgH}_{2}$ and $\mathrm{AlH}_{3}$ with storage capacities of 7.6 and $10.1 \mathrm{wt} \%$, respectively, which equate to volumetric hydrogen densities of $110 \mathrm{~g} / \mathrm{L}$ and $148 \mathrm{~g} / \mathrm{L}$, respectively [10,52,70]. Intermetallic hydrides are formed by combining an element that forms a stable hydride with one that forms an unstable hydride, such as iron-titanium (TiFe), lanthanum-nickel ( $\left.\mathrm{LaNi}_{5}\right)$, magnesium-nickel $\left(\mathrm{Mg}_{2} \mathrm{Ni}\right)$, and zirconium-manganese $\left(\mathrm{ZrMn}_{2}\right)$ alloys $[58,69,71]$. While their gravimetric storage capacity is low ( 2 wt.\%), intermetallic hydrides typically have high hydrogen volumetric capacities (up to $\sim 120 \mathrm{~g} / \mathrm{L}$ ) due to high bulk densities and are available in abundance with good long-term stability [68,71]. In complex metal hydrides, hydrogen is covalently bonded to a metal or non-metal to form a complex anion [10,72]. Complex metal hydrides, such as $\mathrm{NaAlH}_{4}$, typically require high pressures for hydrogen uptake ( $>50$ bars) and high temperatures for dehydrogenation $\left(>200{ }^{\circ} \mathrm{C}\right.$ ) [71-76].

Computational studies suggest that storage volumetric densities higher than that of liquid hydrogen can be obtained via physisorption $[53,77,78]$. Hydrogen molecules are physically adsorbed on the surface of a material (sorbent), usually a micro- or nano-porous solid, and the process is quick and fully reversible $[79,80]$. Metal-organic frameworks 
(MOFs), with polar metal oxide centers and nonpolar organic linkages, have been investigated extensively as hydrogen-sorbent materials [80,81]. Other candidates include zeolites, porous polymeric materials, and carbon-based materials such as carbon nanotubes, carbon foams, graphite, and activated carbon [10,79]. While adsorbent gravimetric storage capacities as high as $10 \mathrm{wt} . \%$ are achievable at cryogenic temperatures (approximately $77 \mathrm{~K}$ ), in most materials, they decrease significantly at room temperature to around $1 \mathrm{wt} . \%$ due to the weak Van der Waals forces between the sorbent material and the hydrogen gas [10,82].

Hydrogen can also be stored chemically in small molecules such as ammonia or methanol as one-way carriers or in organic molecules that can be hydrogenated and dehydrogenated as two-way carriers. Ammonia, the second largest globally produced chemical, can store hydrogen at high gravimetric and volumetric densities in liquid form, $17.8 \mathrm{wt} . \%$ and up to $120 \mathrm{~g} / \mathrm{L}$, respectively $[10,53,59]$. Its synthesis and distribution are well established, and it can be used as a hydrogen carrier for fuel cells or as an energy carrier for direct combustion and has the distinction of being carbon free [53,59]. Methanol can also be used for hydrogen storage via steam reforming, partial oxidation, or thermolysis, which releases $\mathrm{CO}_{2}$ locally if carbon capture is not employed [53]. Another chemical hydrogen carrier suitable for hydrogen storage is formic acid $(4.4 \mathrm{wt} . \%$ and $53 \mathrm{~g} / \mathrm{L}$ at room temperature and pressure) $[10,53,59]$. The hydrogen release process in formic acid is free from carbon monoxide and the carbon dioxide byproduct can be captured and used for the rehydrogenation process [59].

Liquid organic hydrogen carriers (LOHCs) are a subclass of chemical hydrogen carriers, which can be hydrogenated to reach typical hydrogen densities of 5 to $8 \mathrm{wt} . \%[68,83]$. LOHCs are easily transported and stored at room temperature until hydrogen is liberated for use and can be catalytically regenerated for subsequent reuse [84]. Despite moderate hydrogen weight capacities, LOHCs have several advantages over conventional physical storage and other materials-based technologies, including the potential to use existing infrastructure for distribution. Their high densities and low volatility make them analogous to diesel, easing the need for a hydrogen-specific infrastructure. In addition, LOHCs can be stored for extended periods of time without concern for boil-off losses, high pressure and/or low to cryogenic temperature requirements, or materials compatibility issues. In addition, where impurity (NOx, SOx) is a factor, LOHCs can provide very pure hydrogen.

\subsection{Delivery and Distrubtion of Hydrogen for Data Center Applications}

The infrastructure and distribution of hydrogen is integral for the reliable largescale storage necessary for data center backup power. Light-duty vehicles tend to be in the forefront of public forums discussing the hydrogen economy, with a concern over the complexity and logistical challenges that would need to be surmounted for national integration of fueling station infrastructure. In stark contrast, however, data centers within the United States are greatly regionalized, as illustrated in Figure 3. Northern Virginia's Fairfax and Loudoun counties in the greater Washington, DC area, house more data centers per capita than any other area in the world [85] and it is estimated that over $70 \%$ of the world's Internet traffic passes through Ashburn, Virginia, known as "Silicon Valley of the East" and the "Data Center Alley" [86]. Despite the high concentration of facilities in this region, the potential for renewable hydrogen production is low and would require hydrogen to be delivered via pipelines, tube trailers, or tankers. 


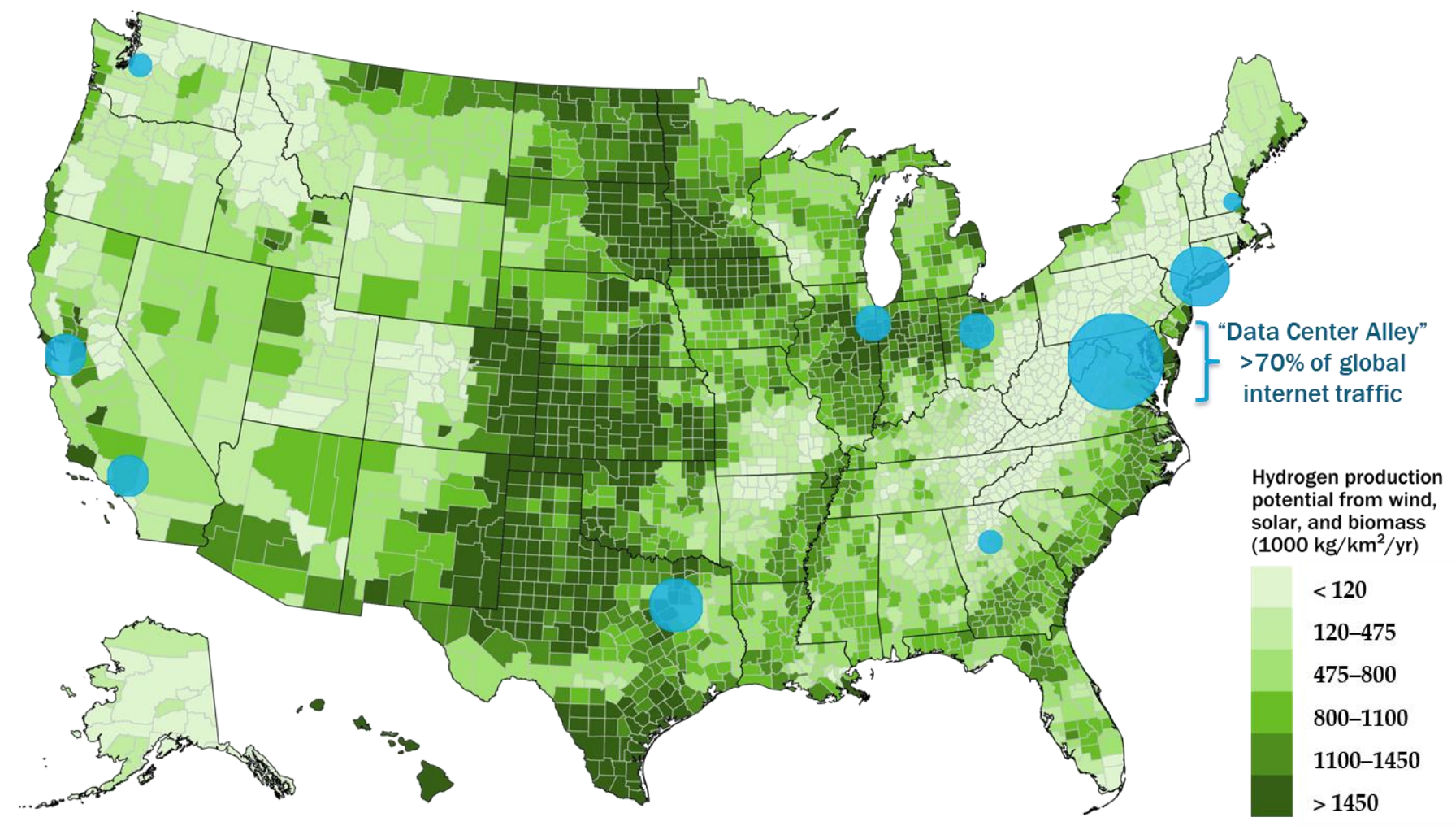

Figure 3. Potential for regional renewable hydrogen production from wind, solar, and biomass with key data center hubs in the United States overlaid (blue circles): Size of the circles approximate the relative number of datacenters in the 10 metropolitan areas in the US with the highest number and concentration of hyperscale data centers, aggregated from sources [87-89].

Regions such as these could benefit from the installation of large-scale, centrally located facilities to supply hydrogen to a multitude of customers on demand over short distances. Metal hydrides and adsorbents have shown potential for numerous applications, from non-mechanical compressors to isotope separation to drug delivery [90]. There has even been some limited commercialization of MOFs in recent years [91-94]; however, while ongoing studies continue to investigate novel materials, neither adsorbents nor metal hydride technologies have been realized for large-scale storage to date [95]. Techno-economic analysis has suggested that LOHCs such as dibenzyltoluene, methanol, and toluene, in contrast, are ready for introduction to the market as these systems are technologically mature [96]. This is even more evidenced by the recent growth in large-scale commercialization and increasing industry adoption. Examples include Hyundai Motor Company's partnership with Hydrogenius LOHC Technology, Chiyoda's partnership with Mitsubishi to mass produce and transport methylcyclohexane produced from toluene, and the Blue Danube project that aims to distribute hydrogen to customers along the Danube River via LOHCs produced by wind and solar. Such operations illustrate how energy stored in LOHCs can be produced in off-site locations and readily transported to provide power as needed on a large scale to regions without substantial renewable hydrogen production.

Salt cavern storage of gaseous hydrogen is another feasible large-scale storage option in regions where salt deposits, such as salt domes and salt beds, at suitable depths ( $\sim 600$ to $2000 \mathrm{~m}$ ) are available $[60,61,63]$. While there are multiple rock-salt deposits across the US, salt domes are primarily located in the Permian Basin in the southern US states of Texas, Mississippi, and Louisiana. Not surprisingly, these areas have been used extensively for natural gas storage. Approximately 13\% ( 240 billion cubic feet) of the US's natural gas working volume in underground storage is stored in salt caverns [97].

Dedicated hydrogen salt cavern storage facilities, however, are few in number. The three operational hydrogen salt dome storage caverns in the US are all located in Texas. 
These caverns are used to supply hydrogen to industrial petroleum partners along the US Gulf Coast [61]. In 2019, the Advanced Clean Energy Storage project was launched in Salt Lake City, Utah to provide large-scale storage of renewable hydrogen, as well as compressed air energy storage in salt dome caverns [98]. This salt cavern storage project represents one of the largest projects of its kind with the potential for 1000 MW of clean energy storage. It is the only salt dome in the Western part of the US with characteristics similar to those available in the US Gulf Coast. In lieu of salt caverns, depleted natural gas deposits across the US, mainly in the North East, Mid-West, and Southwest, may be repurposed for large-scale hydrogen storage [99]. Depleted oil reservoirs are generally unsuitable due to reactions between hydrogen and residual oil, leading to lost hydrogen [60,100]. Further characterization is needed to ascertain the feasibility of types of geologic features other than salt caverns for underground hydrogen storage.

Underground pipelines can be used to link large-scale hydrogen storage facilities to hydrogen production and/or end-use sites [101]. There are approximately 1600 miles $(2575 \mathrm{~km})$ of hydrogen pipelines in the US, primarily along the Gulf Coast [102]. The natural gas pipeline network, however, is more extensive with approximately 3 million miles of pipeline providing access to most areas of the US [103]. Blending hydrogen into these natural gas pipelines is one way to utilize the extensive pipeline network to deliver and/or store hydrogen. Blend limits vary widely across regions and applications and are heavily dependent on the associated pipeline infrastructure (including the materials it is made of and the age and condition of the pipelines) and end-use applications (e.g., turbines for power generation, building equipment). Preliminary research indicates that blending of even small concentrations of hydrogen (e.g., $1 \%$ ) can affect the integrity of pipelines, and that these effects may not change substantially as the blend concentration is increased further [104]. Early analysis also indicates that many end-use applications of natural gas may be able to handle blends of up to $15 \%$ without significant modifications [105]. Recent announcements for demonstrations of blending have included concentrations of up to $30 \%$ in turbine applications. The HFTO has recently funded a collaborative research and development project, HyBlend, which will investigate the long-term effects of blending hydrogen in natural gas pipelines. The project will focus on hydrogen compatibility with the materials in existing pipelines, as well as life cycle and techno-economic analyses, and the results should help spur innovation and growth in this area [106].

\subsection{Current RED for Hydrogen-Based Energy Storage for Large-Scale Applications}

The "Road Map to a US Hydrogen Economy" sees the scale-up of fuel cells, for data centers up to $30 \mathrm{MW}$, as an immediate next step for $\mathrm{H}_{2}$ applications, with an ambitious adoption timeframe of 2020 to 2022 [107]. However, significant challenges remain to be overcome for this prediction to become reality. Currently, the DOE is supporting several activities to address these challenges. The HFTO Funding Opportunity Announcement (FOA) for the 2020 fiscal year included a subtopic on H2@Scale New Market DemonstrationsData Center Demonstrations. A proposal from Caterpillar, Inc. was selected for a USD 6M award for a "System Demonstration for Supplying Clean, Reliable and Affordable Electric Power to Data Centers using Hydrogen Fuel" [108]. The project proposes to demonstrate a 1.5 MW fuel cell backup system powering a data center for 48 continuous hours with liquid hydrogen storage.

HFTO is currently supporting an integrated techno-economic engineering and safety analysis project led by the Savannah River National Laboratory (SRNL) and the NREL that will evaluate a variety of existing storage materials as candidates for the stationary bulk storage of hydrogen when applied to fuel-cell-powered data centers [109]. The analysis will leverage the current work by the NREL in understanding the performance and value proposition of hydrogen and fuel cells for data centers and the materials-based systems modeling and safety, codes, and standards expertise of SRNL. The overarching goal is to define a pathway or evaluate the likelihood of materials-based stationary bulk storage for other applications (starting with fuel-cell-powered data centers) that show potential 
to meet the DOE's ultimate high-volume cost targets for bulk stationary storage ranging from USD $450-$ USD $600 / \mathrm{kg}-\mathrm{H}_{2}$ stored depending on the storage pressure. Preliminary modeling results indicate that metal-hydride-based storage at a feasible mass and pressure could provide enough hydrogen to a fuel-cell-powered backup system to sustain a $20 \mathrm{MW}$ data center for $72 \mathrm{~h}$ [109].

\section{Future Outlook}

The ultimate commercial success of hydrogen technologies for energy storage to supply data centers is dependent on the combination of growing interest and support of data service providers, the availability of reliable and compelling analysis to support economic feasibility, and the availability of high-performance components and reliable installation measures. As time progresses, the adoption will move from data centers and telecommunication towers to backup generators for buildings [107]. As data centers grow in size and number, they will continue to push for greater and greater power requirements making the need for clean energy a necessity, especially as companies set goals of being carbon neutral, and in some cases, carbon negative, by certain dates. Renewable hydrogen is the clear choice to meet these goals since it is energy dense and the only byproduct of producing electricity from a fuel cell is water. At present, the capability for $100 \%$ renewably sourced hydrogen should not preclude the adoption of fuel cell technologies and the advancement of hydrogen storage technologies, where current methods such as steam methane reformation, coupled to carbon capture and storage, may serve as interim means for integrating hydrogen technologies until a transition to fully renewable hydrogen can be realized.

To meet the demands of data center backup power, large-scale storage is critical. Due to the low volumetric density of hydrogen, storage options that provide hydrogen densities greater than compressed gas are needed. Material-based systems provide the necessary densification that would make the on-site storage of hydrogen feasible. Each materialbased system has its own advantages when compared to physical hydrogen storage, while also having its own unique requirements to successfully provide backup power on demand (e.g., system heat exchange, material handling, hydrogen source, etc.) While these factors must be integrated into any storage system design and provide vast potential for future research and development, the wide array of material-based systems offers a versatility not currently available from physical hydrogen storage technologies.

\section{Conclusions}

Hydrogen-based energy storage is a viable option to meet the large scale, long duration energy requirements of data center backup power systems. Depending on the size of the data center or hub, hydrogen storage technologies which can be effectively employed include physical storage in the compressed gas or liquefied state and materials-based storage in solid or liquid hydrogen carriers. For stationary data center energy storage, where mass and volume are not primary concerns, carrier technologies such as metal hydrides and liquid organic hydrogen carriers present several advantages including cost and ease of storage. The realization of hydrogen technologies for data centers would enable the DOE's H2@Scale vision and is an opportunity to both advance current technology and integrate clean, renewable energy in an increasingly energy-demanding information ecosystem.

Author Contributions: A.-D.N.C., M.S. and M.W. contributed equally to this work. Conceptualization, A.-D.N.C., M.S., M.W. and N.T.S.; Investigation, A.-D.N.C., M.S. and M.W.; Writing-Original Draft Preparation, A.-D.N.C., M.S. and M.W.; Writing-Review \& Editing, A.-D.N.C., M.S., M.W. and N.T.S.; Visualization, A.-D.N.C., M.S. and M.W.; Supervision, N.T.S.; Project Administration, N.T.S. All authors have read and agreed to the published version of the manuscript.

Funding: Research received no external funding.

Institutional Review Board Statement: Not applicable. 
Informed Consent Statement: Not applicable.

Data Availability Statement: No new data was generated for this work.

Acknowledgments: The authors thank Genevieve Saur (NREL), Rachel Shepherd (DOE-FEMP), William Gibbons (DOE-HFTO), and Steve Greenberg (LBNL) for their insightful discussions and helpful suggestions for improvement to the manuscript. This research was supported in part by an appointment with the Energy Efficiency \& Renewable Energy (EERE) Science, Technology and Policy Program sponsored by the U.S. Department of Energy (DOE). This program is administered by the Oak Ridge Institute for Science and Education (ORISE) for the DOE. ORISE is managed by ORAU under DOE contract number DE-SC0014664. All opinions expressed in this paper are the authors' and do not necessarily reflect the policies and views of the DOE, ORAU, or ORISE.

Conflicts of Interest: The authors declare no conflict of interest.

Disclaimer: The views and opinions of the authors expressed herein do not necessarily state or reflect those of the United States Government or any agency thereof. Neither the United States Government nor any agency thereof, nor any of their employees, makes any warranty, expressed or implied, or assumes any legal liability or responsibility for the accuracy, completeness, or usefulness of any information, apparatus, product, or process disclosed, or represents that its use would not infringe privately owned rights.

\section{References}

1. U.S. Department of Energy. Secretary Granholm Launches Hydrogen Energy Earthshot to Accelerate Breakthroughs Toward a Net-Zero Economy. Available online: https://www.energy.gov/articles/secretary-granholm-launches-hydrogen-energyearthshot-accelerate-breakthroughs-toward-net (accessed on 2 July 2021).

2. Hydrogen Council. Hydrogen, Scaling Up. Available online: https://hydrogencouncil.com/en/study-hydrogen-scaling-up/ (accessed on 2 July 2021).

3. Staffell, I.; Scamman, D.; Velazquez Abad, A.; Balcombe, P.; Dodds, P.E.; Ekins, P.; Shah, N.; Ward, K.R. The role of hydrogen and fuel cells in the global energy system. Energy Environ. Sci. 2019, 12, 463-491. [CrossRef]

4. Kast, J.; Vijayagopal, R.; Gangloff, J.J.; Marcinkoski, J. Clean commercial transportation: Medium and heavy duty fuel cell electric trucks. Int. J. Hydrogen Energy 2017, 42, 4508-4517. [CrossRef]

5. Lee, D.-Y.; Elgowainy, A.; Kotz, A.; Vijayagopal, R.; Marcinkoski, J. Life-cycle implications of hydrogen fuel cell electric vehicle technology for medium- and heavy-duty trucks. J. Power Sources 2018, 393, 217-229. [CrossRef]

6. Kast, J.; Morrison, G.; Gangloff, J.J.; Vijayagopal, R.; Marcinkoski, J. Designing hydrogen fuel cell electric trucks in a diverse medium and heavy duty market. Res. Transp. Econ. 2018, 70, 139-147. [CrossRef]

7. FuelCellsWorks. DOE Sets Targets for Hydrogen Fuel Cell Trucks. Available online: https://fuelcellsworks.com/news/doe-setstargets-for-hydrogen-fuel-cell-trucks / (accessed on 3 December 2020).

8. U.S. Department of Energy. DOE Launches Two Consortia to Advance Fuel Cell Truck and Electrolyzer R\&D. Available online: https:/ / www.energy.gov/ eere/articles/doe-launches-two-consortia-advance-fuel-cell-truck-and-electrolyzer-rd (accessed on 13 January 2021).

9. U.S. Department of Energy. Department of Energy Announces $\$ 50$ Million for Commercial Truck, Off-Road Vehicle, and Gaseous Fuels Research. Available online: https:/ / www.energy.gov/articles/department-energy-announces-50-million-commercialtruck-road-vehicle-and-gaseous-fuels-0 (accessed on 8 January 2021).

10. Andersson, J.; Grönkvist, S. Large-scale storage of hydrogen. Int. J. Hydrogen Energy 2019, 44, 11901-11919. [CrossRef]

11. U.S. Department of Energy. Hydrogen Shot. Available online: https://www.energy.gov/eere/fuelcells/hydrogen-shot (accessed on 7 July 2021).

12. U.S. Environmental Protection Agency. Current Nonattainment Counties for All Criteria Pollutants. Available online: https: / / www3.epa.gov / airquality/greenbook/ancl.html (accessed on 28 July 2021).

13. Bloomberg Law. Biden's Hefty Clean Air To-Do List Follows Early Big Promises. Available online: https://news.bloomberglaw. com/environment-and-energy/bidens-hefty-clean-air-to-do-list-follows-early-big-promises (accessed on 28 July 2021).

14. U.S. Environmental Protection Agency. Nonattainment Areas for Criteria Pollutants (Green Book). Available online: https: / / www.epa.gov/green-book (accessed on 28 July 2021).

15. The White House. The Path to Achieving Justice40. Available online: https://www.whitehouse.gov/omb/briefing-room/2021 /07/20/the-path-to-achieving-justice40/ (accessed on 28 July 2021).

16. The White House. FACT SHEET: President Biden Takes Executive Actions to Tackle the Climate Crisis at Home and Abroad, Create Jobs, and Restore Scientific Integrity Across Federal Government. Available online: https://www.whitehouse.gov/ briefing-room/statements-releases / 2021/01/27 / fact-sheet-president-biden-takes-executive-actions-to-tackle-the-climatecrisis-at-home-and-abroad-create-jobs-and-restore-scientific-integrity-across-federal-government/ (accessed on 28 July 2021).

17. U.S. Department of Energy. Promoting Energy Justice. Available online: https://www.energy.gov/promoting-energy-justice (accessed on 28 July 2021). 
18. Ponemon Institute Research Report. Cost of Data Center Outages; Ponemon Institute LLC: Traverse City, MI, USA, 2016; pp. 1-20.

19. U.S. Environmental Protection Agency. Summary of the Energy Policy Act (2005). Available online: https://www.epa.gov/lawsregulations/summary-energy-policy-act (accessed on 10 January 2021).

20. U.S. Environmental Protection Agency. Diesel Emissions Reduction Act (DERA) Funding. Available online: https://www.epa. gov / dera (accessed on 14 January 2021).

21. U.S. Environmental Protection Agency. Learn About Impacts of Diesel Exhaust and the Diesel Emissions Reduction Act (DERA). Available online: https:/ / www.epa.gov/dera/learn-about-impacts-diesel-exhaust-and-diesel-emissions-reduction-act-dera (accessed on 8 July 2021).

22. California SB 1099-Emergency Backup Generators: Critical Facilities: Exemptions; State of California: Sacramento, CA, USA, 2020.

23. Worldwide Power Products. Noise Pollution in Diesel Generators. Available online: https://www.wpowerproducts.com/news/ diesel-generator-noise-pollution/ (accessed on 8 January 2021).

24. Techjury. How Much Data Is Created Every Day in 2020? Available online: https://techjury.net/blog/how-much-data-is-createdevery-day/\#gref (accessed on 8 December 2020).

25. SeedScientific. How Much Data Is Created Every Day? [27 Staggering Stats]. Available online: https://seedscientific.com/howmuch-data-is-created-every-day/\#: \{\}:text=Every\%20day \%2C\%20we\%20create\%20roughly \%202.5\%20quintillion \%20bytes \% 20of\%20data (accessed on 14 April 2021).

26. StatInvestor. Information Created Globally 2005-2025. Available online: https://statinvestor.com/data/35219/data-createdworldwide/ (accessed on 14 April 2021).

27. Forbes. 175 Zettabytes By 2025. Available online: https://www.forbes.com/sites/tomcoughlin/2018/11/27/175-zettabytes-by2025/?sh=bbfb42354597 (accessed on 14 April 2021).

28. Statista. Volume of Data/Information Created, Captured, Copied, and Consumed Worldwide from 2010 to 2024 . Available online: https: / / www.statista.com/statistics/871513/worldwide-data-created/\#: \{\}:text=Amount\%20of\%20information\%20 globally\%202010\%2D2024\&text=The\%20total\%20amount \%20of\%20data,reaching\%2059\%20zettabytes \%20in\%202020 (accessed on 14 April 2021).

29. Synergy Research Group. COVID-19 Helps to Accelerate the Shift to Hosted and Cloud Collaboration Solutions. Available online: https://www.srgresearch.com/articles/covid-19-helps-accelerate-shift-hosted-and-cloud-collaboration-solutions (accessed on 2 November 2020).

30. Kurtz, J.; Saur, G.; Sprik, S.; Ainscough, C. Backup Power Cost of Ownership Analysis and Incumbent Technology Comparison; National Renewable Energy Laboratory: Golden, CO, USA, 2014; pp. 1-31. Available online: https:/ /www.energy.gov/eere/fuelcells / downloads/backup-power-cost-ownership-analysis-and-incumbent-technology-comparison (accessed on 10 November 2020).

31. European Committee for Electrotechnical Standarization. CLC/TC 215 Electrotechnical Aspects of Telecommunication Equipment. Available online: https: / / www.cenelec.eu/dyn/www/f?p=104:110:568580276559001::.:FSP_ORG_ID,FSP_PROJECT,FSP_ LANG_ID:1258297,56390,25 (accessed on 10 December 2020).

32. International Organization for Standarization. ISO/IEC TS 22237-1:2018 Information Technology—Data Centre Facilities and Infrastructures-Part 1: General Concepts. Available online: https://www.iso.org/standard/72925.html (accessed on 8 January 2021).

33. International Organization for Standardization. ISO/IEC TS 22237-2:2018 Information Technology—Data Centre Facilities and Infrastructures-Part 2: Building Construction. Available online: https://www.iso.org/standard/73009.html (accessed on 8 January 2021).

34. International Organization for Standardization. ISO/IEC TS 22237-3:2018 Information Technology-Data Centre Facilities and Infrastructures-Part 3: Power Distribution. Available online: https://www.iso.org/standard/73010.html (accessed on 8 January 2021).

35. International Organization for Standardization. ISO/IEC TS 22237-4:2018 Information Technology—Data Centre Facilities and Infrastructures-Part 4: Environmental Control. Available online: https://www.iso.org/standard/73011.html (accessed on 8 January 2021).

36. Telecommunications Industry Association. TIA 942 Certifications \& Ratings. Available online: https://tiaonline.org/productsand-services/tia942certification/tia-942-certifications-ratings/ (accessed on 20 November 2020).

37. Uptime Institute. Data Center Certification. Available online: https://uptimeinstitute.com/tier-certification (accessed on 4 November 2020).

38. Shehabi, A.; Smith, S.; Sartor, D.; Brown, R.; Herrlin, M.; Koomey, J.; Masanet, E.; Horner, N.; Azevedo, I.; Lintner, W. United States Data Center Energy Usage Report; LBNL-1005775; Lawrence Berkley National Laboratory: Guangdong, China, 2016; pp. 1-65.

39. Mitchell-Jackson, J.; Koomey, J.G.; Nordman, B.; Blazek, M. Data Center Power Requirements: Measurements from Silicon Valley. Energy 2003, 28, 837-850. [CrossRef]

40. Masanet, E.; Shehabi, A.; Lei, N.; Smith, S.; Koomey, J. Recalibrating global data center energy-use estimates. Science 2020, 367, 984-986. [CrossRef]

41. Fulton, S., III. How Hyperscale Data Centers Are Reshaping All of IT. Available online: https:/ /www.zdnet.com/article/howhyperscale-data-centers-are-reshaping-all-of-it/ (accessed on 22 November 2020).

42. Allen, M. Data Center Redundancy N+1, N+2 vs. $2 \mathrm{~N}$ vs. $2 \mathrm{~N}+1$. Available online: https://www.datacenters.com/news / datacenter-redundancy-n-1-n-2-vs-2n-vs-2n-1 (accessed on 4 January 2021). 
43. Li, X.; Wang, H.; Yi, S.; Yao, X.; Zhu, F.; Zhai, L. Redundancy-Guaranteed and Receiving-Constrained Disaster Backup in Cloud Data Center Network. IEEE Access 2018, 6, 47666-47681. [CrossRef]

44. Van der Berg, M. An Overview of Complete Power Failures in Data Centers. Available online: http://up2v.nl/2017/06/02 / datacenter-complete-power-failures/ (accessed on 3 December 2020).

45. DatacenterDynamics. 365 Main Offers Transparency with Detailed Root Cause Analysis of Power Outage. Available online: https: / / www.datacenterdynamics.com/en/news/365-main-offers-transparency-with-detailed-root-cause-analysis-ofpower-outage-2/ (accessed on 3 December 2020).

46. Gorman, S. Meltdowns Hobble NSA Data Center. Available online: https://www.wsj.com/articles/SB10001424052702304441404 579119490744478398 (accessed on 20 November 2020).

47. Zhao, L.; Brouwer, J.; James, S.; Peterson, E.; Wang, D.; Liu, J. Fuel Cell Powered Data Centers: In-Rack DC Generation. ECS Trans. 2016, 71, 131-139. [CrossRef]

48. Saur, G.; Arjona, V.; Clutterbuck, A.; Parker, E. Hydrogen and Fuel Cells for Data Center Applications Project Meeting: Workshop Report; NREL/TP-5400-75355; National Renewable Energy Laboratory, U.S. Department of Energy Fuel Cell Technology Office: Golden, CO, USA, 2019; pp. 1-28. Available online: https:/ / www.nrel.gov/docs/fy20osti/75355.pdf (accessed on 4 February 2021).

49. Smith, B. Microsoft Will Be Carbon Negative by 2030. Available online: https://blogs.microsoft.com/blog/2020/01/16/microsoftwill-be-carbon-negative-by-2030/ (accessed on 15 December 2020).

50. Roach, J. Microsoft Tests Hydrogen Fuel Cells for Backup Power at Datacenters. Available online: https://news.microsoft.com/ innovation-stories/hydrogen-datacenters/ (accessed on 3 December 2020).

51. Fuel Cell \& Hydrogen Energy Association. Fuel Cells and Data Centers; Fuel Cell \& Hydrogen Energy Association: Washington, DC, USA; p. 1. Available online: www.fchea.org (accessed on 25 February 2021).

52. Barthélemy, H.; Weber, M.; Barbier, F. Hydrogen storage: Recent improvements and industrial perspectives. Int. J. Hydrogen Energy 2017, 42, 7254-7262. [CrossRef]

53. Kojima, Y. Hydrogen storage materials for hydrogen and energy carriers. Int. J. Hydrogen Energy 2019, 44, 18179-18192. [CrossRef]

54. McWhorter, S.; Read, C.; Ordaz, G.; Stetson, N. Materials-based hydrogen storage: Attributes for near-term, early market PEM fuel cells. Curr. Opin. Solid State Mater. Sci. 2011, 15. [CrossRef]

55. von Colbe, J.B.; Ares, J.-R.; Barale, J.; Baricco, M.; Buckley, C.; Capurso, G.; Gallandat, N.; Grant, D.M.; Guzik, M.N.; Jacob, I.; et al. Application of hydrides in hydrogen storage and compression: Achievements, outlook and perspectives. Int. J. Hydrogen Energy 2019, 44, 7780-7808. [CrossRef]

56. James, B.D.; Huya-Kouadio, J.M.; Houchins, C.; DeSantis, D.A. Mass Production Cost Estimation of Direct $\mathrm{H}_{2}$ PEM Fuel Cell Systems for Transportation Applications: 2018 Update; Strategic Analysis Inc.: Washington, DC, USA, 2017; pp. 1-355. Available online: https:/ / www.energy.gov/sites / prod/files/2019/12/f70/fcto-sa-2018-transportation-fuel-cell-cost-analysis.pdf (accessed on 10 December 2020).

57. Züttel, A. Materials for hydrogen storage. Mater. Today 2003, 6, 24-33. [CrossRef]

58. Krishna, R.; Titus, E.; Salimian, M.; Okhay, O.; Rajendran, S.; Rajkumar, A.; Sousa, J.M.G.; Ferreira, A.L.C.; Campos Gil, J.; Gracio, J. Hydrogen Storage for Energy Application. In Hydrogen Storage; Lui, J., Ed.; IntechOpen: London, UK, $2012 ;$ pp. $243-266$.

59. Niaz, S.; Manzoor, T.; Pandith, A.H. Hydrogen storage: Materials, methods and perspectives. Renew. Sustain. Energy Rev. 2015, 50, 457-469. [CrossRef]

60. Ozarslan, A. Large-scale hydrogen energy storage in salt caverns. Int. J. Hydrogen Energy 2012, 37, 14265-14277. [CrossRef]

61. Lankof, L.; Tarkowski, R. Assessment of the potential for underground hydrogen storage in bedded salt formation. Int. J. Hydrogen Energy 2020, 45, 19479-19492. [CrossRef]

62. Lemieux, A.; Shkarupin, A.; Sharp, K. Geologic feasibility of underground hydrogen storage in Canada. Int. J. Hydrogen Energy 2020, 45, 32243-32259. [CrossRef]

63. Liu, W.; Zhang, Z.; Chen, J.; Jiang, D.; Wu, F.; Fan, J.; Li, Y. Feasibility evaluation of large-scale underground hydrogen storage in bedded salt rocks of China: A case study in Jiangsu province. Energy 2020, 198, 117348. [CrossRef]

64. Ahluwalia, R. 2020 Annual Merit Review: Progress Updates. Available online: https://www.hydrogen.energy.gov/annual_ review20_h2fuel.html\#stor-analysis (accessed on 15 April 2021).

65. Notardonato, W.U.; Swanger, A.M.; Fesmire, J.E.; Jumper, K.M.; Johnson, W.L.; Tomsik, T.M. Final test results for the ground operations demonstration unit for liquid hydrogen. Cryogenics 2017, 88, 147-155. [CrossRef]

66. Swanger, A. Transient Modeling of Large Scale Integrated Refrigeration and Storage Systems. Available online: https://ntrs.nasa. gov/api / citations/20180006597/ downloads/20180006597.pdf (accessed on 10 December 2020).

67. HyMARC. The Hydrogen Materials Advanced Research Consortium. Available online: https://www.hymarc.org/ (accessed on 19 February 2021).

68. Hirscher, M.; Yartys, V.A.; Baricco, M.; von Colbe, J.B.; Blanchard, D.; Bowman, R.C.; Broom, D.P.; Buckley, C.E.; Chang, F.; Chen, P.; et al. Materials for hydrogen-based energy storage-Past, recent progress and future outlook. J. Alloys Compd. 2020, 827, 153548. [CrossRef]

69. Rusman, N.A.A.; Dahari, M. A review on the current progress of metal hydrides material for solid-state hydrogen storage applications. Int. J. Hydrogen Energy 2016, 41, 12108-12126. [CrossRef]

70. Liu, H.; Zhang, L.; Ma, H.; Lu, C.; Luo, H.; Wang, X.; Huang, X.; Lan, Z.; Guo, J. Aluminum hydride for solid-state hydrogen storage: Structure, synthesis, thermodynamics, kinetics, and regeneration. J. Energy Chem. 2021, 52, 428-440. [CrossRef] 
71. Sakintuna, B.; Lamari-Darkrim, F.; Hirscher, M. Metal hydride materials for solid hydrogen storage: A review. Int. J. Hydrogen Energy 2007, 32, 1121-1140. [CrossRef]

72. Milanese, C.; Jensen, T.R.; Hauback, B.C.; Pistidda, C.; Dornheim, M.; Yang, H.; Lombardo, L.; Zuettel, A.; Filinchuk, Y.; Ngene, P.; et al. Complex hydrides for energy storage. Int. J. Hydrogen Energy 2019, 44, 7860-7874. [CrossRef]

73. Sulic, M.; Cai, M.; Kumar, S. Cycling and engineering properties of highly compacted sodium alanate pellets. Int. J. Hydrogen Energy 2012, 37, 15187-15195. [CrossRef]

74. Sulic, M.; Cai, M.; Kumar, S. Controlled degradation of highly compacted sodium alanate pellets. Int. J. Hydrogen Energy 2013, 38, 3019-3023. [CrossRef]

75. Ali, N.A.; Ismail, M. Modification of NaAlH4 properties using catalysts for solid-state hydrogen storage: A review. Int. J. Hydrogen Energy 2021, 46, 766-782. [CrossRef]

76. Chen, W.; You, L.; Xia, G.; Yu, X. A balance between catalysis and nanoconfinement towards enhanced hydrogen storage performance of $\mathrm{NaAlH}_{4}$. J. Mater. Sci. Technol. 2021, 79, 205-211. [CrossRef]

77. Poirier, E.; Chahine, R.; Bose, T.K. Hydrogen adsorption in carbon nanostructures. Int. J. Hydrogen Energy 2001, 26, 831-835. [CrossRef]

78. Barath, J.G.N.; Husev, O.; Manonmani, N. Overview of Energy Storage Technologies for Renewable Energy. Int. J. Innov. Sci. Eng. Technol. 2015, 2, 749-754.

79. Srinivasan, S.; Demirocak, D.; Kaushik, A.; Sharma, M.; Chaudhary, G.; Hickman, N.; Stefanakos, E. Reversible Hydrogen Storage Using Nanocomposites. Appl. Sci. 2020, 10, 4618. [CrossRef]

80. Broom, D.P.; Webb, C.J.; Fanourgakis, G.S.; Froudakis, G.E.; Trikalitis, P.N.; Hirscher, M. Concepts for improving hydrogen storage in nanoporous materials. Int. J. Hydrogen Energy 2019, 44, 7768-7779. [CrossRef]

81. Cherrad, N.; Selloum, D.; Tingry, S. Modeling the control of the desorption rate of hydrogen released from the adsorption storage bed to supply a fuel cell. Int. J. Hydrogen Energy 2020, 45, 17605-17612. [CrossRef]

82. O'Malley, K.; Ordaz, G.; Adams, J.; Randolph, K.; Ahn, C.C.; Stetson, N.T. Applied hydrogen storage research and development: A perspective from the U.S. Department of Energy. J. Alloys Compd. 2015, 645, S419-S422. [CrossRef]

83. Makepeace, J.W.; He, T.; Weidenthaler, C.; Jensen, T.R.; Chang, F.; Vegge, T.; Ngene, P.; Kojima, Y.; de Jongh, P.E.; Chen, P.; et al. Reversible ammonia-based and liquid organic hydrogen carriers for high-density hydrogen storage: Recent progress. Int. J. Hydrogen Energy 2019, 44, 7746-7767. [CrossRef]

84. Teichmann, D.; Arlt, W.; Schlücker, E.; Wasserscheid, P. Transport and Storage of Hydrogen via Liquid Organic Hydrogen Carrier (LOHC) Systems. In Hydrogen Science and Engineering: Materials, Processes, Systems and Technology; Stolten, D., Emonts, B., Eds.; Wiley: Weinhein, Germany, 2016; Volume 1, pp. 811-830.

85. Fairfax County Economic Development Agency. Northern Virginia Leads the World in the Data Center Market. Available online: https: / www.fairfaxcountyeda.org/media-center/northern-virginia-leads-world-data-center-market/ (accessed on 10 March 2021).

86. DigitalTech. Data Center Alley: Why $70 \%$ of Internet Traffic Flows through Ashburn Virginia. Available online: https:// digitaltech.com/data-center-alley-why-70-of-internet-traffic-flows-through-ashburn-virginia/ (accessed on 10 March 2021).

87. National Renewable Energy Laboratory. Geospatial Data Science. Available online: https://www.nrel.gov/gis/data-tools.html (accessed on 11 April 2021).

88. Data Center Map. Data Center Map. Available online: https://www.datacentermap.com/ (accessed on 4 April 2021).

89. Data Centers. Available online: https://www.datacenters.com/ (accessed on 4 April 2021).

90. ThoughtCo. What Is a Metal Hydride? Available online: https://www.thoughtco.com/metal-hydrides-2340044 (accessed on 1 March 2021).

91. Businesswire. NuMat Technologies Closes \$12.4M Funding Round to Accelerate Commercialization of Molecularly Engineered Products. Available online: https: / / www.businesswire.com/news/home/20180426005011/en/NuMat-Technologies-Closes12.4M-Funding-Round-to-Accelerate-Commercialization-of-Molecularly-Engineered-Products (accessed on 1 March 2021).

92. Chemical \& Engineering News. Round Two for MOF Commercialization. Available online: https://cen.acs.org/articles/95/i24/ Round-two-MOF-commercialization.html (accessed on 10 March 2021).

93. Faust, T. MOFs move to market. Nat. Chem. 2016, 8, 990-991. [CrossRef] [PubMed]

94. Sun, Y.; Zheng, L.; Yang, Y.; Qian, X.; Fu, T.; Li, X.; Yang, Z.; Yan, H.; Cui, C.; Tan, W. Metal-Organic Framework Nanocarriers for Drug Delivery in Biomedical Applications. Nano-Micro Lett. 2020, 12, 103. [CrossRef]

95. Ahmed, A.; Seth, S.; Purewal, J.; Wong-Foy, A.G.; Veenstra, M.; Matzger, A.J.; Siegel, D.J. Exceptional hydrogen storage achieved by screening nearly half a million metal-organic frameworks. Nat. Commun. 2019, 10, 1568. [CrossRef]

96. Niermann, M.; Drünert, S.; Kaltschmitt, M.; Bonhoff, K. Liquid organic hydrogen carriers (LOHCs)-Techno-economic analysis of LOHCs in a defined process chain. Energy Environ. Sci. 2019, 12, 290-307. [CrossRef]

97. U.S. Energy Information Association. Weekly Natural Gas Storage Report. Available online: https://ir.eia.gov/ngs/ngs.html (accessed on 15 April 2021).

98. Magnum Development. Magnum Development and Mitsubishi Hitachi Power Systems to Develop 1000 Megawatts of Clean Energy Storage in Central Utah. Available online: https://magnumdev.com/ (accessed on 15 April 2021).

99. Energy Information Administration. The Basics of Underground Natural Gas Storage. Available online: http:/ / large.stanford. edu/publications/power/references/gastore/ (accessed on 16 April 2021). 
100. Tarkowski, R. Underground hydrogen storage: Characteristics and prospects. Renew. Sustain. Energy Rev. 2019, 105, 86-94. [CrossRef]

101. Bünger, U.; Michalski, J.; Crotogino, F.; Kruck, O. 7-Large-scale underground storage of hydrogen for the grid integration of renewable energy and other applications. In Compendium of Hydrogen Energy; Ball, M., Basile, A., Veziroğlu, T.N., Eds.; Woodhead Publishing: Oxford, UK, 2016; pp. 133-163. [CrossRef]

102. Penev, M.; Hunter, C. Regional Supply of Hydrogen. Available online: https:/ / www.hydrogen.energy.gov/pdfs / review18/sa0 63_penev_2018_p.pdf (accessed on 16 April 2021).

103. U.S. Energy Information Association. Natural Gas Explained-Natural Gas Pipelines. Available online: https:/ /www.eia.gov/ energyexplained/natural-gas/natural-gas-pipelines.php (accessed on 10 April 2021).

104. San Marchi, C.W.; Simmons, K.L. Considerations of Hydrogen Compatibility of Materials for Blending Hydrogen into the Natural Gas Network. United States, 2020-04-01. Available online: https:/ /www.osti.gov/biblio/1775062-considerations-hydrogencompatibility-materials-blending-hydrogen-natural-gas-network (accessed on 14 January 2021).

105. National Renewable Energy Laboratory. New Report Analyzes Options for Blending Hydrogen into Natural Gas Pipelines. Available online: https:/ / www.nrel.gov/news/program/2013/2143.html (accessed on 2 July 2021).

106. National Renewable Energy Laboratory. HyBlend Project to Accelerate Potential for Blending Hydrogen in Natural Gas Pipelines. Available online: https:/ / www.nrel.gov / news/program/2020/hyblend-project-to-accelerate-potential-for-blending-hydrogenin-natural-gas-pipelines.html (accessed on 15 April 2021).

107. Fuel Cell \& Hydrogen Energy Association. Road Map to a U.S. Hydrogen Economy. Available online: https://static1 .squarespace.com/static/53ab1feee4b0bef0179a1563/t/5e7ca9d6c8fb3629d399fe0c/1585228263363/Road+Map+to+a+US+ Hydrogen+Economy+Full+Report.pdf (accessed on 28 December 2020).

108. U.S. Department of Energy. Energy Department Announces Approximately $\$ 64 \mathrm{M}$ in Funding for 18 Projects to Advance H2@Scale. Available online: https:/ / www.energy.gov/articles/energy-department-announces-approximately-64m-funding-18-projectsadvance-h2scale (accessed on 8 December 2020).

109. Hardy, B.; Ruth, M. Determining the Value Proposition of Materials-Based Hydrogen Storage for Stationary Bulk Storage of Hydrogen. Available online: https://www.hydrogen.energy.gov/pdfs/review21/st228_hardy_2021_o.pdf (accessed on 1 July 2021). 